\title{
KARAKTERISTIK PASTA BAWANG MERAH (Allium ascalonicum L.) BERDASARKAN PERBEDAAN SISTEM EMULSI
}

\author{
Anni Nuraisyah ${ }^{1 *}$, Wawat Rodiahwati ${ }^{2}$, Ariskanopitasari ${ }^{3}$, Rhestu Isworo ${ }^{4}$, Mikhratunnisa $^{5}$
}

$1^{*}$ Program Studi Teknologi Industri Pertanian Universitas Teknologi Sumbawa

2,3,5 Program Studi Teknologi Industri Pertanian Universitas Teknologi Sumbawa

3 Program Studi Teknologi Hasil Pertanian Universitas Teknologi Sumbawa

*Corresponding Author email: anni.nuraisyah@uts.ac.id,rhestu,isworo@uts.ac.id, mikhratunnisa@uts.ac.id

\begin{tabular}{ll}
\hline \multirow{2}{*}{$\begin{array}{l}\text { Diterima : } \\
\text { Bulan Januari }\end{array}$} & Abstrak \\
\cline { 2 - 3 } 2021 & Kabupaten Bima mempunyai potensi besar dalam menghasilkan bawang merah (Allium \\
& ascalonicum L.) karena dapat ditanam sepanjang tahun sehingga berlimpah produksinya \\
& bawang merah. Pengolahan bawang merah bertujuan untuk mempertahankan umur \\
& simpan dan mutu bawang merah. Penelitian ini membandingkan karakteristik pasta \\
Diterbitkan : & bawang merah dengan dua sistem pengemulsi yang berbeda. Penggunaan sistem emulsi \\
Bulan Februari & yang tepat mempengaruhi mutu pasta bawang merah. Penelitian dilakukan dalam skala \\
2021 & laboratorium menggunakan rancangan acak lengkap (RAL) dengan dua perlakuan dan \\
& tiga kali ulangan, perlakuan pertama penambahan shortening dengan lesitin, dan \\
Keyword: & perlakuan kedua penambahan pati dengan kelapa sawit. Karakteristik pasta bawang \\
Pasta Bawang & merah yang ingin diteliti yaitu kadar air (AOAC 2005), kadar protein (AOAC, 2005) dan \\
Merah, ready to & kadar lemak (AOAC, 2005). Hasil pengujian pasta bawang merah menunjukkan bahwa \\
use, emulsi, & Perlakuan penambahan CMC 0.3\% 7 menit memiliki kadar air paling rendah (44,11\%). \\
lemak, pati & Sedangkan penambahan lesitin 6\% 4 menit memiliki kadar air yang lebih tinggi \\
& dibandingkan perlakuan yang lain (51,27\%). Kadar protein paling tinggi terdapat pada \\
& perlakuan penambahan CMC 0.3\% 7 menit yaitu 3.05\%. sedangkan terendah pada \\
& perlakuan penambahan lesitin 6\% 4 menit yaitu 2.63\%. Kadar lemak pasta bawang merah \\
& tertinggi terdapat perlakuan dengan penambahan CMC sebesar 0,3\% dengan waktu \\
& penumisan 7 menit (0.89\%), sedangkan terendah terdapat pada perlakuan dengan \\
& penambahan lesitin 6\% dengan waktut penumisan 4 menit (0,82\%).
\end{tabular}

\section{PENDAHULUAN}

Bawang merah (Allium ascolanicum L.) merupakan salah satu komoditas sayuran unggulan Indonesia. Volume total permintaan bawang merah mencapai 576.900 ton (1). Kabupaten Bima mempunyai potensi besar dalam menghasilkan bawang merah karena dapat ditanam sepanjang tahun. Dengan potensi tersebut, Kabupaten Bima memberikan kontribusi besar terhadap kebutuhan nasional (2). Bawang merah Bima memiliki keunggulan tahan terhadap cuaca sehingga dapat ditanam sepanjang tahun. Namun demikian, secara nasional harga jual bawang merah bersifat fluktuatif (3). Bawang merah dimanfaatkan sebagai bumbu dan rempah dalam masakan, sehingga dibutuhkan sepanjang tahun. Harga bawang merah ketika panen sangat rendah, karena ketersediaan bawang merah yang berlimpah, hal ini merugikan petani. Namun diluar masa panen, harga bawang merah sangat tinggi karena ketersediaannya berkurang, hal ini merugikan masyarakat (konsumen). Oleh karena itu diperlukan alternatif pengolahan bawang merah agar ketersediaan dan harga bawang merah tetap stabil. Pengolahan bawang merah bertujuan untuk mempertahankan mutu bawang merah sebelum digunakan.
Trend saat ini, populasi wanita bekerja semakin meningkat sehingga waktu yang dibutuhkan untuk menyiapkan makanan terbatas (4). Selain itu industri pangan (seperti restoran, hotel, rumah sakit, katering) juga membutuhkan bahan pangan yang ready to cook untuk mempercepat proses pengolahan, penanganan, dan penyimpanan. Proses pengolahan bawang merah dapat menyebabkan mata perih karena adanya volatil (tripopanal sulfoksida) (5). Disisi lain, bawang merah hampir digunakan untuk seluruh jenis olahan makanan Indonesia. Produk ready to use atau produk ready to cook merupakan salah satu stratetgi untuk mempermudah proses pengolahan pangan sebelum ke tahap lanjutan. Salah satu produk ready to use bawang merah yaitu bawang merah iris (6). Selain itu banyak juga buah potong yang biasa kita lihat di Supermarket yang memudahkan konsumen untuk mengkonsumsinya. Pasta bawang merah merupakan sediaan produk ready to use yang lebih kompleks dibandingkan bawang iris.

Pasta bawang merah menjadi alternatif produk sediaan bumbu yang memiliki flavor yang kuat, sehingga dapat memberikan aroma yang khas ketika digunakan. Pasta bawang merah merupakan bahan pangan beremulsi yang harus stabil komponen lemaknya dan tersebar merata serta tidak 
menggumpal atau terkoagulasi. Namun demikian kadar air bawang merah sangat tinggi dan merupakan senyawa polar sehingga perlu adanya emulsifier agar sistem emulsi terbentuk dengan baik (7).

Penggunaan minyak kelapa sawit dan pati pada pengolahan pasta sebagai pembentuk sistem emulsi akan membantu selama proses ataupun sesudah pengolahan, sehingga hasil akhir yang diperoleh adalah pasta bawang dengan penyebaran partikel yang merata (8). Selain itu lemak nabati juga menjadi alternatif lain untuk membentuk sistem emulsi dengan emulsifier berupa lesitin ditambah dengan shortening.

Shortening merupakan lemak nabati yang memiliki sifat nonpolar berfungsi sebagai pengikat senyawa polar dalam bawang merah. Penambahan shortening bertujuan untuk membentuk sifat plastis pada pasta bawang merah (9). Selain itu, shortening juga banyak digunakan sebagai media untuk menggoreng, karena adanya emulsifier yang terdapat di dalam shortening menyebabkan bahan dapat dimasak pada suhu yang lebih rendah. Lesitin dengan nama lain fosfatidilkolin termasuk dalam jenis emulsifier (10). Lesitin suatu fosfolipid yang merupakan komponen utama fraksi fosfatida yang dapat diisolasi dari kuning telur dan kacang kedelai, yang diekstrak secara mekanik maupun kimiawi. Tujuan penambahan lesitin yaitu untuk memperoleh hasil pasta bawang merah yang lebih homogen serta mengikat senyawa aroma dalam bawang merah selama proses pembuatan sehingga aromanya dapat dipertahankan.

Pembentukan sistem emulsi antara kelapa sawit dan pati dibandingkan dengan shortening dan lesitin menjadikan karakteristik pasta bawang merah yang berbeda. Dengan demikian, perlu dilakukan penelitian dengan judul karakteristik pasta bawang merah (Allium ascalonicum L.) berdasarkan perbedaan sistem emulsi.

\section{LANDASAN TEORI}

\section{Bawang merah}

Bawang merah merupakan tanaman musiman yang berbentuk rumput, berbatang pendek dan berakar serabut, tinggi dapat mencapai 15-20 $\mathrm{cm}$ dan membentuk rumpun. Akarnya berbentuk akar serabut yang tidak panjang. Jumlah perakaran tanaman bawang merah dapat mencapai 20-200 akar, dengan diameter bervariasi antara 0.5-2 mm. Bentuk daun tanaman bawang merah seperti pipa, yakni bulat kecil memanjang antara $50-70 \mathrm{~cm}$, berlubang, bagian ujungnya meruncing, berwarna hijau muda sampai hijau tua dan letak daun melekat pada tangkai yang ukurannya relatif pendek. Pangkal daunnya dapat berubah fungsi seperti menjadi umbi lapis (11).
Tanaman dari genus Allium memiliki karakteristik rasa dan aroma yang sangat kuat, hal ini disebabkan adanya senyawa-senyawa sulfur didalamnya (12). Aroma segar dari genus Allium sebagian besar terdiri dari komponen sulfur. Pada bawang merah, komponen sulfur terdiri atas thiosulfinates (Ti) dan zwiebelanes (Zw). Senyawa sulfur dari bawang merah yang merupakan prekusor flavor, memberikan bau khas pada bawang, semakin tinggi kadar VRS semakin tajam baunya. Senyawa sulfur memiliki sifat volatil, sehingga kadar sulfur akan berkurang saat bawang merah dilukai (13). Flavor bawang dapat dipengaruhi oleh beberapa faktor diantaranya adalah keadaan selama pertumbuhan termasuk umur tanaman, kandungan sulfur tanah dan kandungan air, keadaan setelah panen, serta pengolahan lebih lanjut.

Senyawa volatil yang terdapat dalam bawang merah ialah hidrogen sulfida, thiol, disulfida, trisulfida dan thiosulfinat. Flavor bawang merah terbentuk dari aktivitas enzim allinase terhadap senyawa prekursor tidak berbau di dalam bawang. Saat jaringan bawang merah rusak, maka prekursor flavor utama yang disebut S-1-propanil-Lsistein sulfoksida akan terhidrolisis dengan cepat oleh enzim allinase membentuk asam sulfonat, asam piruvat dan amonia. Selanjutnya asam sulfonat berubah menjadi tiopropanal S-oksida yaitu suatu senyawa volatil yang jika mengenai mata mengakibatkan perih dan keluarnya air mata pada saat bawang diiris (14).

\section{Pasta bawang merah}

Pasta bawang merah adalah produk olahan dari bawang merah dengan bentuk plastis seperti margarin atau mentega. Proses pengolahan pasta bawang merah dilakukan dengan beberapa tahapan yaitu persiapan bahan berupa pengupasan, pencucian, dan penirisan bawang merah. Kemudian pengecilan ukuran bawang merah dengan menggunakan food processor. Bawang yang dihancurkan tidak ditambahkan air dalam proses dihasilkannya bubur bawang merah. Bubur bawang merah yang sudah terbentuk kemudian dicampurkan dengan lemak nabati dan emulsifier. Setelah tercampur dan terbentuk adonan pasta, dilakukan pemasakan dengan cara penumisan diatas kompor dengan api sangat kecil. Pemanasan dengan penumisan ini dilakukan berdasarkan pada kebiasaan masyarakat dalam mengawetkan bumbu. Penumisan ini bertujuan untuk membunuh mikroba patogen pada produk pangan. Penumisan dilakukan pada suhu $85-90{ }^{\circ} \mathrm{C}$. Pengadukan saat penumisan dilakukan agar pasta homogen. Penumisan dilakukan selama 20 menit. Setelah penumisan, pasta didinginkan dan kemudian dikemas dengan wadah jar steril.

Pasta merupakan produk emulsi yang bersifat plastis seperti mentega atau margarin yang 
berbentuk padat tetapi dapat dioleskan. Sifat bahan padat lunak dan dapat diubah-ubah bentuknya jika dikenakan suatu gaya. Tekstur pasta mempunyai bentuk antara padat dan cair. Emulsi dikatakan sebagai dua cairan ata lebih yang terdispersi dalam suasana koloid. Faktor yang mempengaruhi sistem emulsi antara lain: jenis protein, lemak, suhu, kecepatan pengadukan, dan proses penggilingan. Shortening adalah lemak padat yang mempunyai sifat plastis dan kestabilan tertentu, umumnya berwarna putih dan sering disebut mentega putih. Bahan ini diperoleh dari hasil pencampuran dua atau lebih lemak dengan cara hidrogenasi. Shortening yang ditambahkan pada adonan dapat memberi tekstur yang lembut dan kaya rasa, menambah keempukan dan mencegah terjadinya aerasi untuk menjaga kelembaban dan penambahan ukuran.

Lesitin dengan nama lain fosfatidilkolin, suatu fosfolipid yang merupakan komponen utama fraksi fosfatida yang dapat diisolasi dari kuning telur dan kacang kedelai, yang diekstrak secara mekanik maupun kimiawi menggunakan heksan. Lesitin secara komersial untuk keperluan pengemulsi, dan lesitin efektif menurunkan tegangan antarmuka antara lemak dan air, tetapi mampu menjaga kestabilan emulsi dalam adonan. Lesitin yang digunakan sebagai bahan tambahan merupakan lesitin nabati yang berbentuk cair. Tujuan penambahan emulsifier yaitu untuk memperoleh hasil pasta bawang merah yang lebih homogen (15).

\section{METODE PENELITIAN}

\section{Alat dan Bahan}

Peralatan yang dibutuhkan untuk pembuatan pasta bawang merah adalah neraca digital, pisau, sendok, wadah, panci, blender, wajan jenis teplon cekung, spatula dan kompor gas.

Bahan yang digunakan pada penelitian ini antara lain bawang merah varietas Bima, lesitin, margarin putih, minyak kelapa sawit, dan maltodextrin. $\mathrm{HCl}, \mathrm{NaOH}$, Natrium tiosulfat, indikator pati, fenolftalein, aseton, $\mathrm{KMnO}_{4}$, aquadest, $\mathrm{H}_{2} \mathrm{SO}_{4}$, larutan $\mathrm{KI}, \mathrm{Na}_{2} \mathrm{~S}_{2} \mathrm{O}_{3}$, amilum, asam asetat glacial, alkohol, kloroform.

\section{Persiapan dan karakterisasi bawang merah}

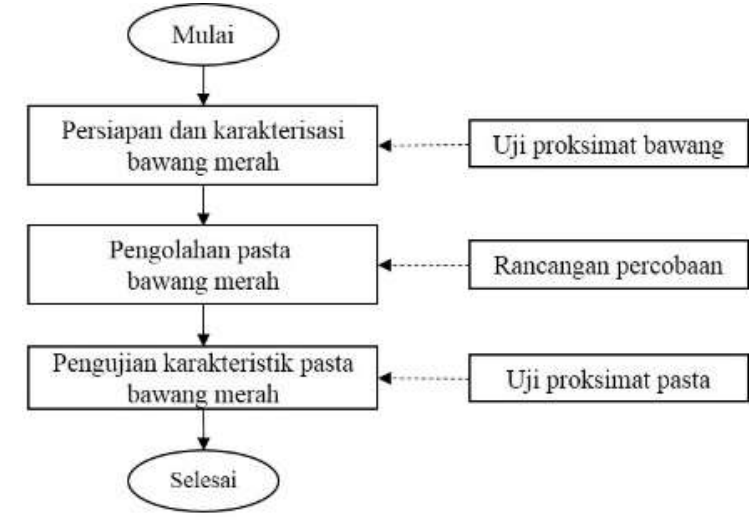

\section{Pengolahan pasta bawang merah}

Pengolahan pasta bawang merah meliputi penggilingan, pencampuran dengan emulsifier, penumisan, dan pengemasan. Proses penggilingan dilakukan dengan blender selama 30 detik. Pada proses pencampuran, menggunakan dua perlakuan emulsi; (A1) lesitin dan mentega putih, dan (A2) kelapa sawit dan maltodextrin. Pencampuran dilakukan dengan menggunakan blender agar homogen. Waktu pencampuran yang diperlukan untuk menghasilkan pasta bawang merah selama 3 menit. Setelah proses pencampuran, pasta bawang merah ditumis selama 3 menit 30 detik pada suhu $80-85^{\circ} \mathrm{C}$, kemudian didinginkan. Selanjutnya, pasta bawang merah dikemas dengan gelas kemasan (jar) dan dilakukan pengujian kadar air, kadar protein dan kadar lemak. Penelitian ini menggunakan Rancangan Acak Lengkap (RAL) dengan dua perlakuan dan empat kali ulangan. Perlakuan pertama sistem emulsi dengan penambahan shortening dan lesitin, sedangkan perlakuan kedua penambahan pati dengan minyak kelapa sawit. Serta kontrol, yaitu tanpa perlakuan keduanya.

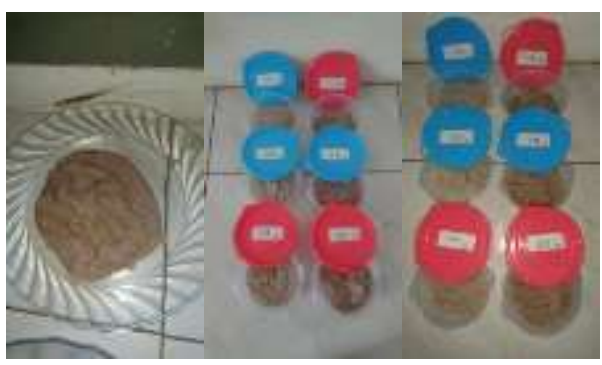

Gambar 1. Pasta Bawang Merah

\section{HASIL DAN PEMBAHASAN}

\section{Karakterisasi bawang merah}

Hasil karakterisasi kimia bawang merah sebelum dilakukan pengolahan menjadi pasta adalah sebagai berikut: 
Tabel 1. Data Karakterisasi Bawang Merah

\begin{tabular}{|l|c|}
\hline Parameter uji proksimat & Rata-rata \\
\hline kadar lemak (\%) & 0,34 \\
\hline kadar air (\%) & 85,77 \\
\hline kadar protein (\%) & 1,56 \\
\hline
\end{tabular}

Berdasarkan data tersebut dapat diketahui, bahwa sampel bawang merah bima memiliki nilai kadar lemak 0,34 \%; kadar air 85,77\%; kadar protein 1,56\%; kadar abu 0,09\%; dan kadar serat 0,06\%. Data tersebut digunakan untuk membandingkan hasil uji poksimat bawang merah apabila sudah mengalami proses pengolahan menjadi pasta bawang merah.

\section{Kadar Air Pasta Bawang Merah}

Kadar air merupakan salah satu sifat kimia dari bahan yang menunjukkan banyaknya kadar air yang terkandung didalam bahan pangan. Penentuan kadar air merupakan analisis paling penting dan luas dilakukan dalam pengolahan dan pengujian pangan. Kadar air berpengaruh langsung terhadap stabilitas dan kualitas pangan (1). Hasil analisis kadar air dari pasta bawang dengan variasi penambahan emulsifier dan lama waktu penumisan ditunjukkan pada Gambar 2.

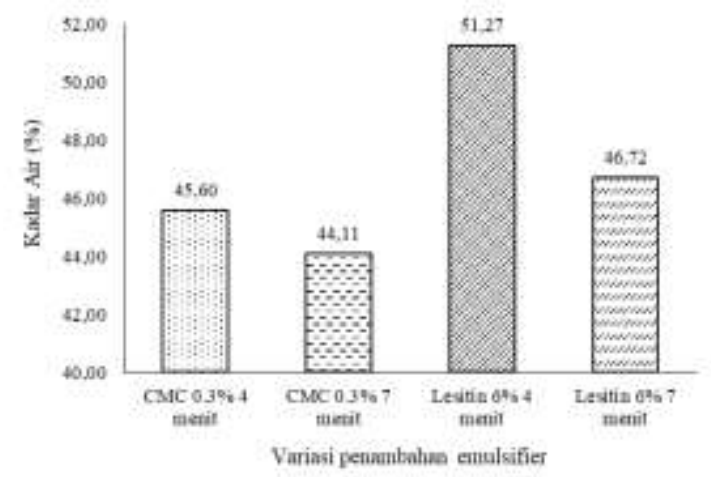

Gambar 2 Grafik kadar air pasta bawang merah

Gambar 2 menunjukkan kadar air pasta bawang merah pada berbagai variasi penambahan emulsifier (CMC dan Lesitin) dan lama waktu penumisan (4 menit dan 7 menit). Perlakuan penambahan CMC 0.3\% 7 menit memiliki kadar air paling rendah $(44,11 \%)$. Sedangkan penambahan lesitin 6\% 4 menit memiliki kadar air yang lebih tinggi dibandingkan perlakuan yang lain $(51,27 \%)$. CMC dan lesitin merupakan dua jenis emulsifier yang berfungsi untuk menstabilkan produk. Keduanya memberikan pengaruh terhadap kandungan air dari pasta bawang merah.

Pengaruh CMC terhadap berkurangnya kadar air di karenakan sifat CMC yang dapat menyerap air sebab memiliki gugus hidrofilik, banyaknya air yang diserap bergantung pada kadar CMC yang di tambahkan dalam pasta bawang merah, makin besar kadar CMC maka gugus hidrofilik semakin banyak sehingga jumlah air yang yang terserap makin banyak, setelah air diserap oleh CMC kemudian dilakukan pemanasan kadar air yang terserap oleh CMC mengalami penguapan mengakibatkan kecenderungan kadar air dalam sampel semakin rendah (2).

Waktu penumisan juga berpengaruh dalam penurunan kadar air pasta (3), bahwa semakin lama waktu pemanasan maka pemecahan komponen komponen bahan semakin meningkat yang berakibat pada jumlah air terikat yang di bebaskan semakin banyakhal inidapat dilihat dari hasil penumisan 4 menit memiliki kadar air yang lebih banyak dibandingkan waktu penumisan 7 menit. Penumisan berpengaruh terhadap kadar air dimana menurut Aisyah (2014), sayuran yang ditumis mempunyai kadar air relatif rendah daripada sayuran yang direbus atau dikukus. Hal ini karena matrik jaringan sayuran yang semula terisi oleh air serta komponen organik lainnya akan terdegradasi, kemudian keluar dari jaringan dan digantikan oleh misel-misel minyak. Bahan segaryang ditumis, maka kulit bagian luar akan mengerut akibat proses dehidrasi (5). Pengerutan terjadi akibat panas dari minyak menguapkan air yang terdapat pada bahan makanan. Selama proses menumis berlangsung, sebagian minyak akan masuk ke dalam bahan kemudian mengisi ruang kosong yang semula diisi air dan komponen organik lainnya.

Penambahan emulsifier dengan CMC merupakan perlakuan terbaik untuk pasta bawang merah adalah dengan penambahan CMC sebesar $0,3 \%$ karena menghasilkan kadar air terendah yaitu $45,60 \%$. Dimana kadar air yang didapat lebih rendah dibandingkan dengan yang lainnya.

\section{Kadar Protein Pasta Bawang Merah}

Protein adalah zat makanan yang penting bagi tubuh karena mempunyai fungsi sebagai zat pembangun dan zat pengatur tubuh. Protein merupakan sumber asam-asam amino yang mengandung unsur karbon, hidrogen, oksigen dan nitrogen (6). Pengujian kadar protein ini penting untuk mengetahui perubahan kadar protein dari pasta bawang.

Protein bawang merah memiliki kadar yang cukup tinggi, kadar protein bawang merah itu sendiri (7), adalah sebesar 1,5 gram dari 100 gram bawang merah dan merupakan komponen terbanyak kedua setelah karbohidrat. Kadar protein yang diperoleh pada pasta bawang merah dengan penambahan bermacam kadar emulsifier dan waktu penumisan dapat dilihat pada Gambar 3.

Gambar 3 menunjukkan kadar protein paling tinggi terdapat pada perlakuan penambahan CMC $0.3 \% \quad 7$ menit yaitu $3.05 \%$. sedangkan 
terendah pada perlakuan penambahan lesitin $6 \% 4$ menit yaitu $2.63 \%$. Kadar protein akan meningkat kepekatannya sejalan dengan berkurangnya kadar air dalam bahan pangan (8). Penggunaan CMC dapat mengikat air yang terdapat dalam bahan pangan dimana terdapat gugus hidrofilik yang dapat mengikat air, sehingga kadar air mengalami penurunan serta pemanasan juga mempengaruhi berkurangnya kadar air. Penstabil CMC memiliki kelebihan salah satunya adalah dapat mencegah pengendapan protein. Penggunaan CMC dalam industri pangan juga dapat berfungsi mencegah terjadinya retrogradasi atau kerusakan pada protein dan pengendapan protein pada titik isoelektriknya. Hal ini disebabkan oleh bergabungnya gugus karboksil dari CMC gugus karboksilnya menjadi bermuatan negatif (terdeprotonasi, -COO-) dengan muatan gugus positif dari protein (terprotonasi, $\mathrm{NH} 3+$ ) maka asam amino bersifat zwitter ion (9).

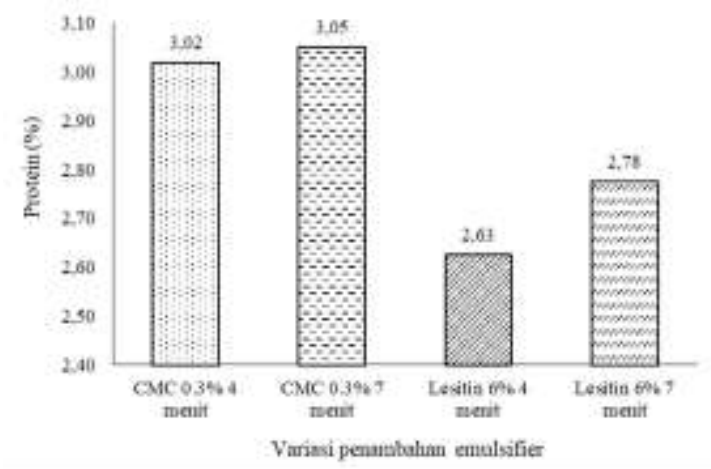

Gambar 3 Kandungan protein pasta bawang merah

Lama waktu penumisan juga berpengaruh terhadap meningkatnya kepekatan dari protein disebabkan semakin lama waktu penumisan maka kadar air dalam pasta bawang merah mengalami penurunan. Hal ini dikarenakan semakin lama waktu pemanasan maka air yang di uapkan semakin banyak sehingga kadar air yang dikandung semakin menurun. Dapat dilihat pada tabel bahwa dengan waktu penumisan 7 menit memiliki kadnungan protein lebih tinggi di bandingkan dengan waktu penumisan 4 menit.

\section{Kadar Lemak Pasta Bawang Merah}

Lemak merupakan biomolekul yang sangat penting dalam kebutuhan makan kita. Lemak adalah sumber cadangan kalori yang memiliki energi tinggi. Jika dibandingkan dengan metabolism karbohidrat dan protein yang menghasilkan energy sekitar 4 sampai $5 \mathrm{kkal} / \mathrm{g}$, sedangkan lemak menghasilkan $9 \mathrm{kkal} / \mathrm{g}$. lemak merupakan senyawa organik yang terdapat di alam serta tidak larut dalam air, tetapi larut dalam pelarut organik nonpolar,misalnya dietil eter $\left(\mathrm{C}_{2} \mathrm{H}_{5} \mathrm{OC}_{2} \mathrm{H}_{5}\right)$, kloroform $\left(\mathrm{CHC}_{13}\right)$, benzena dan hidrokarbon lainnya, lemak dan minyak dapat larut dalam pelarut yang disebutkan di atas karena lemak dan minyak mempunyai polaritas yang sama dengan pelarut tersebut (10). Lemak di dalam pasta bawang merah berfungi juga sebagai sistem pengemulsi, sehingga didapat produk dengan pengemulsi yang baik.

Pengujian atau analisis kadar lemak ini bertujuan untuk mengetahui kadar lemak pada sampel pasta bawang merah, sebab dalam proses pembuatan pasta bawang merah ditambahkan lemak nabati yang berasal dari minyak goreng kelapa sawit yang memungkinkan menjadikan bertambahnya kandungan lemak. Kadar lemak yang diperoleh pada pasta bawang merah dengan penambahan bermacam kadar CMC dan waktu penumisan pada Gambar 4.

Gambar 4 menunjukkan kadar lemak pasta bawang merah pada perlakuan penambahan emulsifier dan lama waktu penumisan. Berdasarkan hasil perhitungan diatas dapat disimpulkan bahwa kadar lemak pasta bawang merah tertinggi terdapat perlakuan dengan penambahan CMC sebesar 0,3\% dengan waktu penumisan 7 menit (0.89\%), sedangkan terendah terdapat pada perlakuan dengan penambahan lesitin $6 \%$ dengan waktut penumisan 4 menit $(0,82 \%)$

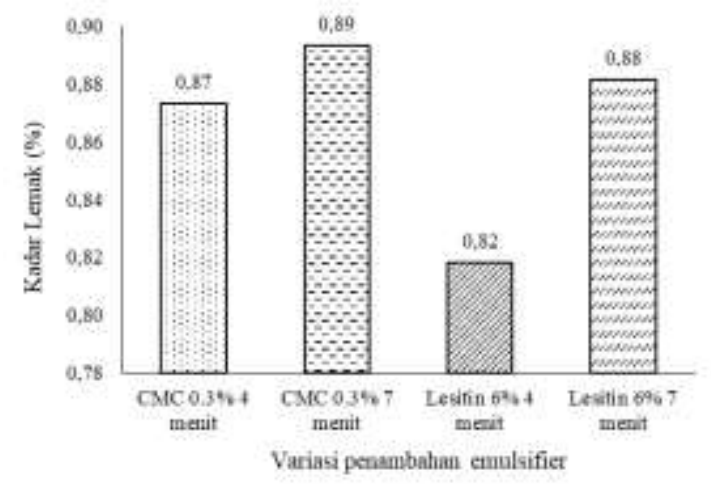

Gambar 4 Kandungan lemak pasta bawang merah

Kenaikan nilai kadar lemak ini terus berlangsung dengan semakin banyak kadar CMC yang diberikan dan juga waktu penumisan juga berpengaruh dimana dengan waktu 7 menit kadar lemak yang didapat lebih tinggi dari waktu penumisan 4 menit. Hal ini dikarenakan semakin banyak CMC yang ditambahkan maka gugus hidrofobik semakin tinggi sehingga berpengaruh terhadap peningkatan kadar lemak pasta bawang merah serta penurunan kadar air yang disebabkan oleh penumisan.

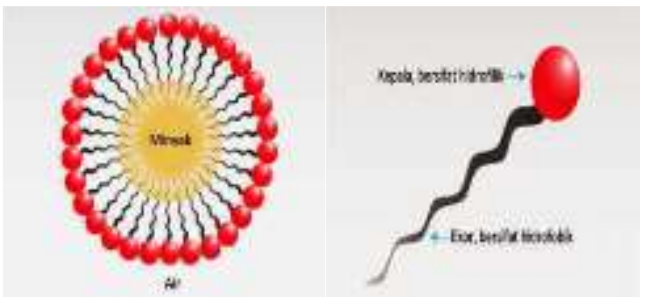

Gambar 5 Mekanisme kerja CMC (Edubio, 2014) 
CMC merupakan senyawa yang memiliki gugus hidrofobik sebagai gugus pengikat lemak dan hidrofilik sebagai gugus pengikat air (11). Maka CMC yang merupakan senyawa yang memiliki gugus hidrofobik mengikat lemak yang berasal dari minyak goreng, dengan demikian semakin banyak gugus hidrofobik maka semakin banyak lemak yang terikat dengan gugus tersebut. Waktu penumisan juga mempengaruhi kadar lemak dari pata bawang merah dimana pada waktu penumisan 7 menit didapatkan hasil lebih tinggi dibandingkan dengan waktu penumisan 4 menit.

Hal ini dikarenakan hubungan korelasi antara kadar air dan kadar lemak adalah korelasi negatif. Semakin tinggi kadar lemak yang terkandung maka semakin rendah kadar air tersebut (12). Hal ini sesuai dengan hasil pengamatan pada kadar air dimana kadar air pada waktu penumisan 7 menit lebih rendah sehingga kadar lemaknya lebih tinggi.

\section{PENUTUP}

\section{Kesimpulan}

Hasil peneilitian menunjukkan bahwa Penambahan emulsifier dengan CMC merupakan perlakuan terbaik untuk pasta bawang merah adalah dengan penambahan CMC sebesar 0,3\% karena menghasilkan kadar air terendah yaitu 45,60\%. kadar protein paling tinggi terdapat pada perlakuan penambahan CMC $0.3 \% 7$ menit yaitu $3.05 \%$. sedangkan terendah pada perlakuan penambahan lesitin 6\% 4 menit yaitu $2.63 \%$. kadar lemak pasta bawang merah tertinggi terdapat perlakuan dengan penambahan CMC sebesar 0,3\% dengan waktu penumisan 7 menit $(0.89 \%)$, sedangkan terendah terdapat pada perlakuan dengan penambahan lesitin $6 \%$ dengan waktut penumisan 4 menit $(0,82 \%)$

\section{REFERENSI}

1. Sundari, D., Almasyhuri. Dan Lamid, A. 2015. Pengaruh Proses Pemasakan Terhadap Komposisi Zat Gizi Bahan Pangan Sumber Protein. Media Litbangkes. Vol. 25 No. 4: 235 -
242

2. Kamal, N. 2010. Pengaruh Bahan Aditif CMC (Carboxyl Methyl Cellulose) Terhadap Beberapa Parameter Pada Larutan Sukrosa. Jurnal Teknologi Vol. I. Edisi. 17: 78-84

3. Hadawiyah, R., Yasa, I.W.S. dan Sulastri, Y. 2018. Pengaruh Lama Penghangatan dalam Alat Pemasak Nasi Terhadap Mutu Nasi Beras Merah (Oryza Nivara). Artikrel Ilmiah. Mataram: Fakultas Teknologi Pangan dan Agroindustri Universitas Mataram

4. Ketaren, S. 2005. Minyak Dan Lemak Pangan. Jakarta;Penerbit Universitas Indonesia. Halaman 284

5. Sundari, D., Almasyhuri. Dan Lamid, A. 2015. Pengaruh Proses Pemasakan Terhadap Komposisi Zat Gizi Bahan Pangan Sumber Protein. Media Litbangkes. Vol. 25 No. 4: 235 242

6. Ratnawati. 2017. Pengendalian Hama dan Penyakit Pada Tanaman Bawang Merah. Aceh: BPTP Aceh

7. Adawyah. 2007. Pengolahan dan Pengawetan Ikan. Jakarta: Bumi Aksara.

8. Prabandari, W. 2011. Pengaruh Penambahan Berbagai Jenis Bahan Penstabil Terhadap Karakteristik Fisikokimia dan Organoleptik Yoghurt Jagung. Skripsi. Surakarta: Fakultas Pertanian Universitas Sebelas Maret Surakarta

9. Herlina, N. dan Ginting, M.H.S. 2002. Lemak dan Minyak. USU digital library. Medan: Fakultas Teknik Jurusan Teknik Kimia Universitas Sumatera Utara.

10. Ketaren, S. 2005. Minyak Dan Lemak Pangan. Jakarta;Penerbit Universitas Indonesia. Halaman 284.

11. Fitriani., dan Awaliyah, N. 2015. Pengaruh Suhu Ekstraksi danLama PemanasanTerhadap Stabilitas Pigmen Antosianin dan Karatenoid.Majalah Ilmiah Al Ribaath, Universitas Muhammadiyah Pontianak. Vol 12, No. 1. 35-43ISSN: $1412-7156$.

12. Tocmo R, Lin Y dan Huang D. 2014. Effect of Processing Condition on the organosulfides of shallot (Allium cepa L. Agregatum Group). Journal Agri Food Chem. 62: 5296-5304. 